\title{
NEW TENDENCIES IN THE HUNGARIAN AGRI-FOOD QUALITY POLICY
}

\author{
NOVE TENDENCIJE U MAĐARSKOJ POLITICI KVALITETE \\ U POLJOPRIVREDNO-PREHRAMBENOM SEKTORU
}

\author{
Dr László Vajda \\ Hungary/Mađarska \\ E-mail: vajda.laszloeu@gmail.com
}

UDK/UDC:338.43.02:005.6

JEL klasifikacija/JEL classification: Q18:L15

DOI: $10.30657 / \mathrm{hdmk} .2020 .30$

Pregledni članak/Review

Jezik/Language: Engleski/English

\section{SUMMARY}

New elements, aspects are arising or getting stronger value, like environment-conciousness, social responsibility. There are also word-wide and EU-wide changes in the stucture of the agri-food industry, in the management policies of food production, marketing, logistics. Therefor the present and the future of Hungarian agri-food industry widely depends on recognising and adapting to world-wide tendencies. This paper describes some of the important changes in the agri-food industry and the reactions to that within the Hungarian agri-food quality policy.

Key words: quality, agri-food, quality policy, new tendencies.

\section{INTRODUCTION}

Quality of agri-food products and services comprises both the fulfilness of the expectations of the consumers and the ressource-efficient organisation of the company. While these imminent elements of the quality are stable, there are many variations and changes in their realisation. Consumer expectations are changing, also the availability and cost of the ressources (financial, technical, human). New elements, aspects are arising or getting stronger value, like environment-conciousness, social responsibility. There are also word-wide and EU-wide changes in the stucture of the agri-food industry, in the management policies of food production, marketing, logistics.

This paper describes some of the important changes in the agri-food industry and the reactions to that within the Hungarian agri-food quality policy.

\section{WORLD-WIDE TENDENCIES}

World population is growing, especially in Africa and Asia, thus the main challenge for the agri-food sector is to ensure food security, to provide enough food. Still because of economic growth and welfare, in many parts of the world demand for quality food is also 
increasing and with that the requirements of consumers and also of retailers that producers have to meet as quality criteria. The Food and Agriculture Organisation (FAO) of the United Nations makes multiple efforts to teach producers of developing countries to meet quality food requirements at the world market (e.g. geographical indications schemes of the EU) and to adopt cost effective quality management practices (e.g. HACCP ${ }^{1}, \mathrm{EUROGAP}^{2}, \mathrm{IFS}^{3}$ ).

In 2016 the European Union established an International panel of Experts on Sustainable Food Systems (IPES) with the goal to determine the way towards a Common Food Policy of the EU. The IPES document requires a new governance framework and sets 5 objectives for building sustainable food systems in Europe. Another IPES document from November 2019 urges CFS (FAO Committee on World Food Security) to take bold action on agroecology.

The International Organisation of standards (ISO) renews from time to time its standars, which are accepted and adopted in all parts of the world. The serie ISO 9000 is on good quality management practices, the most important element being ISO 9001 on the set of standardized requirements for a quality management síystem. In 2015 a new version of ISO 9001 was issued. In this version focus is on risk-based thinking, more than before and also greater emphasis on leadership engagement.

ISO 14001 on environment management system help organisations to improve their environmental performance through more efficient use of ressources and reduction of waste.

ISO 22000 deals the Food security management Systems. After 2005 a new standard was published in 2018, which now comprisies animal feed and pet food as well.

Sustainability is an aspect, which becomes higher and higher significance in all areas of our life, as well as in food production. Sustainabilty, the ability of continue even increasing food production in harmony with the nature, is for more and more people an imminent element of the quality of the food they buy and eat. Sustainabiltiy is also a more and more important aspect of the quality management schemes.

In modern management systems a company must show social responsibility. We are all responsible for the future of our society, both individuals and companies. More and more consumers decide for food, produced at every segment of the food chain by socially responsible and sustainable practices. ISO/ /TS 26030 is recent Guidance appearing in January 2020 on the application in the food chain of the standard ISO 26000:2010 on social responsibility and sustainable development.

Sustainability and social responsibility help to protect environment. Still production and trade go already for decades in the direction of globalisation, of idustrialisation. A tendency to fight these developments and to keep production in harmony with nature, with traditions is agro-ecology. These producers and their customers wish to break away from industrial food and farming systems. The initiatives are often kick-started by community-building activities, by farmer researcher partnerships, sometimes by external shocks. Producers and consumras look for short supply chaines, both get often familiarized which each other through long-term contacts.

\section{HUNGARIAN ANSWERS TO THE NEW TENDENCIES}

Based ont the favourable natural conditions (topography, climate, soil, water) agriculture and processing industry are traditionally strong sectors of the Hungarian economy, selling both on domestic and international markets a wide range of products. Therefor the

\footnotetext{
${ }^{1}$ Hazard Analysis and Critical Control Points.

${ }^{2}$ EUREPGAP is a global system and framework for Good Agricultural Practice whereby manages the EUREPGAP Secretariat.

${ }^{3}$ International Food Standard.
} 
present and the future of Hungarian agri-food industry widely depends on recognising and adapting to world-wide tendencies.

After long and thorough preparation the Hungarian Government adopted in 2015 a Food Industry Development Strategy. The strategy is based an a SWOT analysis, speaking also about the weaknesses, like weak competitivity, low profitability, weakneses in the human capacities. Anyhow Hungarian food industry buys and processes $65 \%$ of the domestic agricultural production and the share of the exported food made $38-41 \%$ of the total food production in the years 2014-2018. So the three main objectives of the Strategy are:

- increase in the quality,

- development of the conciousness of the consumers, and

- increase of the efficiency of the food authorities.

In 2017 the Strategy was followed by an Action Plan, consisting of 20 points. For the period 2021-2027 the main objectives of the development of the food industry are:

- support to innovative projects,

- hogher value added products, using digitalisation and robotisation,

- increase of knowledge of consumers ont he foodstuffs, forming their mentality,

- increase of the effectiveness of ressources,

- decrease of the burden on environment,

- education and training of the manpower.

Several funds were allocated to support the objectives. Within the EU Rural Development Program of Hungary for 2014-2020 a special budget line was allocated for investments into the small and medium sized food enterprises, which was followed by another special budget line in the Program for Development of Economy and Innovation (GINOP) for the medium-sized companies. When deciding on the applications, quality and innovation were the main criteria. Also within the Rural Developmnet Program a special allocation was dedicated for the development and adoption of $\mathrm{EU}\left(\mathrm{PDO}^{4}, \mathrm{PGI}^{5}, \mathrm{TSG}^{6}\right.$, organic production) and Hungarian quality labels.

In Hungary a Food Book (Codex Alimentarius Hungaricus) was established to support the quality-orientation of the food companies. This Food Book was reviwed ad republished in 2018-2019 with the purpose of making it more efficient and adopting to the world-wide food quality tendencies. The different chapters on food quality, food additives, labelling, food control etc. are based on EU legislation and are published as Decrees of the Minister of Agriculture. They can all be found in the Inventory of the Food Regulations of the National Food Chain Safety Authority (NÉBIH).

To support the objective of increasing the quality, Hungary introduced a new quality label: Food of Excellent Quality (Kiváló Minőségű Élelmiszer, KMÉ), which is step by step extended to all food products. The first product group receibving the right to use the loge were dairy products at the end of 2019. The label has two levels: Base level and Gold level. The main criteria for the selection by a committeee, designated by the Minister of Agriculture are: quality, food safety and packaging.

Beside the new label the system and prestige of the existing EU and Hungarian quality labels is strengthened. Among them a special place is deserved by the HÍR-Program (Hagyományok-Ízek-Régiók, Traditions, Tastes, Regions), which started in 1998 and by 2000 it comprised a collection of 300 Hungarian agri-food products, food dishes. In 2010 the Ministry

\footnotetext{
${ }^{4}$ Protecdet Designation of Origin - covers agricultural products and foodstuffs which are produced, processed and prepared in a given geographical area using recognised know-how.

${ }^{5}$ Protected Geographical Indication - covers agricultural products and foodstuffs closely linked to the geographical area. At least one of the stages of production processing and preparation takes place in the area.

6 Traditional Speciality Guaranteed - highlights traditional character, either in the composition or means of production.
} 
of Agriculture launched applications for HÍR trademark and by the end of 2018 already 176 products benefitted of fulfilling the criteria. This label is already well-known $(39,6 \%)$ by the Hungarian consumers and about $10 \%$ of them are especially looking in the shops for products with this trademark. Receiving the HIR trademark is for many producers a first step ont he road for application for EU food quality trademarks (PDO, PGI, TSG).

Another change for the adoption of world-wide tendencies and challenges is in the name, objective and activities of the Hungarian organisation of food producers. The name since 2019 is „Organisation of Responsible Food Producers”. One of the basic aims of the organisation is to create sustainable food production and supply based on a sustainable diet of the consumers. The organisation aims also on a strengthened communication with the consumers to convince them about the quality and the healthy nature of the products of its member companies. In 2019 they started a communication campaign under the slogan „Hallo Food", which explains the quality-mindness and the social responsibility of the members. The organisation also helds close contacts to Food Drink Europe, the European organisation of food and drink industries and to IPES-Food.

Agr-ecology is still in initial phase in Hungary and spatially rather sporadic. Still there are a few communities in Hungary, which are commiteed to this mentality and this practice. A community in Eastern Hungar, Hernádszentandrás, wher ecological production and marketing is one of the keybones of the community, even uses as slogan a variation of its name: "Bioszentandrás". There are communities in the surroundings of big cities, like Budapest and Nyiregyháza, which have direct contracts with clients in the city and supplying to them 2-3 times weekly their own fresh or stored vegetables. In November 2019 a 2-days conference summerised experience and stimulated further development, organised in Budapest by the Institut Francais and the Ministry of Agriculture.

Exchange of experience on quality management in the agri-food sector and promotion of the practices is organised by the Hungarian National Committee of the European Organisaion of Quality (EOQ MNB), which has a Section for Agriculture and Food Industry. EOQ MNB cooperates with the Ministry of Agriculture, with profesional organisations, research institues, universities, having among its members both organisations and private persons. The event of outstanding importance is the yearly "Conference on Quality Management in the Food industry", taking place in the city of Szeged in the Autumn months. The speakers are representstives of the Ministry, of research institutes and companies, the around 100 participants come from all sub-sectors of the industry. The conference is at the same time summary of the present best practices and exchange of views on future developments. The 2019 conference, already the XVI-th in row, was held October 15.

An important aspect of food quality is the research and the practice in connection of packaging materials. For decades the outstanding aspect of packaging was the preservation of the product packed and its role in the marketing. In recent years extensive research is done connected to the environmental and health aspects. Analysis shows, that $96 \%$ of packaging materials goes to waste and most of it harms to environment, see the state of rivers and seas. According a report of the Wessling Hungary Ltd, people consume daily $10 \mathrm{mg}$, during an 80 years life about 300 gr of migrating packaging materials. An increasing part of consumers refuse buying drinks in plastic materials, prefer buying food in bulk or in own, returning packaging material.

\section{CONCLUSION}


Education and training is a further important element of quality policy. Hungary has longstanding traditions in this field. Quality of agri-food products, quality control, quality assurance uis part of the traing at agricultural faculties. On the other hand, quality manager education is realised basically at facultirs for industrial engineers, like at the Pannon University in Veszprém, the Budapest Technical University (BME). These courses consist generally of 2 semesters and about 60-80 credits, while at Óbuda University, Budapest the course lasts 4 semesters, comprises 480 hours and 120 credits. The only specialised food quality manager education takes place at the University of Sciences, Szeged. For a diploma of Specialized Manager for Food safety the course lasts 2 semeseters, comprises 25 hours and 80 credits; for a Manager for Quality Systems the course is 2 semesters and consists of 200 hours and 60 credits. If a food safety manager additionally covers 85 hours of the discipline „Quality management", he/she may obtain a Certificate of EOQ Food Safety System Manager. Interested applicants can also receive this certificate at courses organised by the Hungarian National Committeee of EOQ itself. This certificate is issued in accordance with the EOQ and is continously adopted to the new world-wide quality policy tendencies.

\section{Summary:}

\section{NOVE TENDENCIJE U MAĐARSKOJ POLITICI KVALITETE U POLJOPRIVREDNO-PREHRAMBENOM SEKTORU}

Pojavljuju se novi elementi, aspekti ili dobijaju na snažnijoj vrijednosti, poput svjesnosti za okoliš, društvene odgovornosti. Postoje također promjene $i$ na razini EU u strukturi poljoprivredno-prehrambene industrije, u politikama upravljanja proizvodnjom hrane, marketingom, logistikom. Zbog toga sadašnjost $i$ budućnost mađarske poljoprivrednoprehrambene industrije uvelike ovisi o prepoznavanju i prilagođavanju svjetskim tendencijama. Ovaj rad opisuje neke od važnih promjena u poljoprivredno-prehrambenoj industriji i reakcije na nju unutar mađarske politike o kvaliteti poljoprivredno-prehrambenih proizvoda.

Ključne riječi: kvaliteta, poljoprivredno-prehrambena politika, politika kvalitete, nove tendencije.

\section{LITERATURE:}

1. Contribution to the Zero Draft of the CFS Policy Convergence Process on Agroecological and other Innovative Approaches, IPES-Food, 29 November 2019.

2. Cost-effective management tools for ensuring food quality and safety for SME-s, Modul 2, Modul 3; FAO, Rome, 2011.

3. Felkai, Beáta, „Agrárminisztérium: Élelmiszeripari sajátosságok aktualitásai”, presentation at the XVI-th Conference on Quality Management in the Food Industry, Szeged, October $15,2019$.

4. Food safety risk management - Evidence-informed policies and decisions, considering multiple factors, FAO, Rome, 2017.

5. Geographical Indication Systems in Croatia, Hungary and Poland - Synthesis report, FAO, Budapest, 2018.

6. Magyarország közép- és hosszútávú élelmiszeripari fejlesztési stratégiája; Földmüvelésügyi Minisztérium, Budapest, 2015.4.23. 
7. Szöllősi, Réka, „Nemzetközi kihívások az élelmiszeriparban”, presentation at the OMÉK Conference, Budapest, September 26, 2019.

8. Szigeti, T., „Wessling Hungary Kft: Élelmiszeripari csomagolóanyagok vizsgálata és hulladékainak környezetre gyakorolt hatása" presentation at the XVI-th Conference on Quality management in the Food Industry, Szeged, October 15, 2019.

9. Török, A., „A HIR-védjegy ismertsége és beágyazódottsága a magyar fogyasztók körében - The recognition and the embeddness of the TTR trademark among the consumers" The Hungarian Journal of Nutrition marketing, Budapest, Nr 1, 2019.

10. Towards a Common Food Policy for the EU - The Policy Reform and Realignement that is required to build sustainable Food Systems in Europe, IPES-Food, February 2019.

11. Website:franciaintezet.hu/articles/universite-recherche/evenements/colloqueagroecologie.html 